\title{
Narsisizm Bağlamında Lüks Tüketim ${ }^{1}$ (Araştırma Makalesi)
}

\author{
Luxury Consumption in the Context of Narcissism \\ Doi: 10.29023/alanyaakademik.829565
}

Yelda ÜLKER

Arş. Gör., Marmara Üniversitesi, İletişim Fakültesi

yeldaulker@hotmail.com

Orcid No: 0000-0001-8105-2686

Bu makaleye atıfta bulunmak için: Ülker, Y. (2021). "Narsisizm Bağlamında Lüks Tüketim”. Alanya Akademik Baklş, 5(2), Sayfa No.1015-1030.

\author{
Anahtar kelimeler: \\ Narsisizm, \\ Lüks Tüketim, \\ Lüks Markalar, \\ Tüketici Davranışları \\ Makale Geliş Tarihi: \\ 21.10.2020 \\ Kabul Tarihi: \\ 23.03.2021
}

\section{Keywords:}

Narcissism,

Luxury Consumption,

Luxury Brands,

Consumer Behavior

\section{ÖZET}

Günümüzde narsist kişilik özelliklerine sahip bireylerin saylsında artış gözükmektedir (Wallace ve Baumeister, 2002: 819). Gösterişe önem veren ve teşhirci davranışlar sergileyen narsist kişilerin maddiyatçı bir tutum sergiledikleri görülmektedir. Bu bağlamda başkalarına kendilerini beğendirme ve onay alma ihtiyacı hisseden narsist kişilerin, genellikle gösterişçi ve lüks markalara yöneldikleri söylenebilir. Bunun en büyük sebebi narsist kişilerin ihtiyacı olan farklı olma, özgün olma, yüksek statüye sahip olma gibi arzu ve isteklerin, lüks markalar tarafindan karşılamasıdır. Bu bağlamda araştırmada narsist kişilik özellikleriyle, lüks tüketimleri arasında bir ilişkinin olup olmadiğının irdelenmektedir. Bu amaç doğrultusunda yapılan çalışmada elde edilen verilere göre, narsist kişilik özellikleriyle, lüks tüketimleri arasında anlaml bir ilişkinin olduğu görülmektedir. Ayrıca narsist kişilik özelliklerinin alt boyutlar olan "hayranlı" ve "rekabet" unsurlarının da lüks tüketimleri arasında anlaml bir ilişkinin olduğu belirlenmiştir.

\section{ABSTRACT}

Today, there seems to be an increase in the number of individuals with narcissistic personality traits. It is seen that narcissists who attach importance to show-off and exhibit exhibitionistic behaviors have a materialistic attitude. In this context, it can be said that narcissist people who feel the need to appreciate and get approval from others generally turn to ostentatious and luxurious brands. The biggest reason for this is that the desires and desires of narcissists such as being different, being unique and having high status are met by luxury brands. In this context, the research examines whether there is a relationship between narcissistic personality traits and their luxury consumption. According to the data obtained in the study conducted for this purpose, it is seen that there is a significant relationship between narcissistic personality traits and luxury consumption.

\footnotetext{
${ }^{1} \mathrm{Bu}$ makale Marmara Üniversitesi Sosyal Bilimler Araştırma Etik Kurulu'nun 19.11.2020 tarihli ve 2020/28 sayılı kararı ile etik olarak uygun bulunmuştur.
} 


\section{GİRIŞ}

Günümüzde ruh sağlığı uzmanları, adını Mitolojideki Narkissos'un hikayesinden alan narsisizmin arttığını ve insanlarda daha sık görülmeye başladığını belirtmektedir (BBC NEWS, 2019; Wallace ve Baumeister, 2002: 819). Kendilerini diğer insanlardan önemli ve üstün gören narsist kişiler, kendilerini diğer insanlara gösterme çabası içinde olup, negatif yönlü eleştiriye katlanamamaktadır. Fakat bu bireyler genellikle kendilerinde başkalarını küçümseme, eleştirme ve sömürme hakkını bulmaktadır. Kendilerine ve hayatlarına odaklı yaşayan narsist kişiliğe sahip bireyler, çıkarcı tutum ve davranışlar göstermekte, kibirli davranmakta ve diğer insanlar içinde baskın bir karakter olarak kendisini göstermektedir. Tüm bu özelliklerine rağmen narsist kişiliğine sahip bireyler, başka insanların ilgisine, beğenisine ve onaylamasına ihtiyaç duymaktadır.

Kendisini sevme ve başkalarından üstün görme olarak kabul edilen ve bir kişilik bozukluğu olan narsisizm, bireylerin yaşam tarzlarına, davranışlarına, çevreleriyle olan ilişkilerine ve tüketim tutumlarına yansımaktadır. Bu bağlamda narsist bireyler olmak istedikleri veya oldukları kişilik özellikleri yansıtmak için seçtikleri markalar, gittikleri mekanlar gibi şeyleri başkalarına da gösterme ihtiyacı hissetmektedir. Diğer bir deyişle, narsisizme sahip bireylerin, gösterişe önem vermesi ve teşhirci davranışlar sergilemesinden dolayı, maddiyatçı bir tutum içinde oldukları varsayılabilir. Bu bağlamda narsist bireylerin, gösterişçi ve lüks markalara yöneldikleri söylenebilir. Çünkü lüks markalar, tüketicilerin farklılaşmasına, başkalarından daha yüksek bir statüye sahip olmasına ve kendilerine diğerlerinden daha farklı bir anlam yüklemelerine sebep olmaktadır. Özellikle lüks markaların sınırlı sayıda olması, her yerde satılmaması, fiyatının yüksek olması gibi özellikler lüks markaya sahip olan kişilerin güçlü bir haz duymasına sebep olmaktadır. Bununla birlikte lüks markalar ulaşılır olma durumları açısından "giriş", "orta", "üst" ve "elit" seviye olarak kendi içlerinde ayrışmaktadır (Heine, 2012). Örneğin Mercedes, giriş seviyede, Dolce \& Gabbana orta seviyede, Armiani üst seviyede ve Puiforcat adlı marka ise elit seviyede değerlendirilmektedir (Tosun, vd., 2018: 633). Bir markanın bulunması ne kadar zor ve fiyatı ne kadar yüksekse, tüketiciler o lüks markayı kullanarak duydukları hazın seviyesi de o kadar yüksek, tatmin olması o kadar fazladır denilebilir. Bu şekilde lükse yönelerek kendilerine sembolik değerler yükleyen tüketicilerin, narsist duygularının güçlendiği söylenebilir. $\mathrm{Bu}$ bağlamda narsist kişilik özelliğine sahip bireylerin gösterişçi, lüks, özgün ve farklılık niteliklerini barındıran markalara yöneldiği varsayılabilir.

$\mathrm{Bu}$ çerçevede araştırma kapsamında bireylerin narsist kişilik özellikleriyle, lüks tüketimleri arasında bir ilişkinin olup olmadığının belirlenmesi amaçlanmaktadır. Ayrıca araştırma bağlamında narsist kişilik özelliğinin alt boyutları olan "hayranlık" ve "rekabet" unsurlarının lüks tüketimle arasında bir ilişkisinin olup olmadığı da irdelenmiştir. Ayrıca çalışmada narsisizmin alt boyutlarından olan "hayranlı" ve "rekabet" faktörlerinin, lüks tüketim eğiliminin alt boyutları olan "ürün benzersizliği”, "pahalılık", "sembolik anlam”, "keyfi arzu” ve "münhazır bir azınlığa ait olmak" faktörleri arasında bir ilişkinin olup olmadığı da incelenmiştir. İlgili literatür incelendiğinde tüketicilerin spesifik kişisel özellikleriyle ilgili yeterli araştırmaya rastlanmamıştır. $\mathrm{Bu}$ durum da ileride tüketicilerin farklı kişisel özellikleriyle ilgili yapılabilecek çalışmalara yol gösterici olacağına inanılmaktadır. Ayrıca araştırmanın sonuçlarının lüks markaların iletişsim stratejilerini belirlemesine de yardımcı olacağı düşünülmektedir. 


\section{KAVRAMSAL ÇERÇEVE}

\subsection{Narsisizm Kavramı}

Kökeni, Yunan mitolojisinde suya yansıyan aksini görüp, kendisine hayran kalarak, âşı olan ve hayatını asla ulaşamayacağı sudaki sevgiliyi izleyerek geçiren Narkissos'dan gelen narsisizm kavramı (Wallace ve Baumeister, 2002: 819), günümüzde kendini beğenen, teşhircilik yapan ve kendilerini başkalarından üstün gören bireyler için kullanılmaktadır (Cisek vd, 2014: 1). Diğer bir deyişle narsist eğilimler gösteren kişilerde kibir, diğer insanlara karşı üstünlük kurma, kendini mükemmel görme ve görkemlilik gibi davranışlar bulunmaktadır (Kubarych, Deary ve Austin, 2004). Narsisizm ile ilgili çalışmalar klinik gözlemlere dayanıyor olsa da kavramla ilgili kuramsal ve ampirik çalışmalar özellikle son y1llarda artarak devam etmektedir (Aydın ve Akgün, 2014: 46). Narsizm kavramı ilk olarak Havelock Ellis (1898) tarafindan tanımlansa da bu kavram Freud (1914) tarafindan önemli ölçüde geliştirilmiştir. Günümüzde narsisizm kişilik özelliklerine sahip bireyler, kendilerini diğer insanlardan önemli ve üstün görmektedir. Bu sebeple kendilerini gösterme çabası içinde olup, eleştiriye katlanamamakta ve başkalarını sömürme hakkını kendilerinde bulmaktadır. Kendine odaklı bir hayat yaşayan, baskın karakterli, kibirli davranan narsist kişiliğe sahip bireyler, diğer insanların aşırı ilgisine ve onaylamasına muhtaçtırlar. Bu bilgiler 1şığında narsisizmin kişilik bozukluğu olduğu söylenebilir (Kubarych, Deary ve Austin, 2004; Cisek vd, 2014). Salmivalli de (2001) narsist kişiliğe sahip bireylerde, empati eksikliği, başkalarına kıyasla bazı ayrıcalıklara sahip olduğu düşüncesi ve diğerlerini sömürme gibi ortak özelliklerin bulunduğunu belirtmektedir. Özkaya'nın (2018) yapmış olduğu araştırmaya göre narsist kişiliğe sahip bireylerin cinsiyet ve yaş değişkenleri arasında anlamlı bir fark bulunmamaktadır. Fakat bu kişiliğine sahip bireylerin sosyal medyaya karşı bağımlı olduğu görülmektedir (Buffardi ve Campbell, 2008: 1303-1305; Mehdizadeh, 2010: 357-358). Bunun sebebi narsist bireylerin, kendilerini yansıtan şeyleri başkalarına gösterme ihtiyacı hissetmeleridir (Ünlü, 2018: 168). Çevresindeki kişilerle sürekli çatışma halinde olan, karşısındaki insanları rakip olarak gören narsist kişiler, bu çatışmalardan dolayı mutsuz olmaktadır (Demirci ve Ekşi, 2017: 54). Kernberg'de (1988) bu tarz kişilerde, kıskançlık, teşhir ve sadece kendisiyle ilgilenme gibi davranışların olduğunu belirtmektedir. Narsist kişiler, kendileri için aşırı zaman ve enerji harcamanın yanı sıra, diğer insanların dikkatini çekmek ve iyi görünmek de istemektedir (Avcılar ve Atalar, 2019: 1376). Çünkü narsist bireyler, sahip olduklarını başkalarına göstermek istemektedir (Buss ve Chiodo, 1991: 213). $\mathrm{Bu}$ bağlamda, narsist kişiler, üstün ve görkemli imajlarını başkalarına göstermek için lüks, özel ve gösterişçi tüketim eğilimindedirler (Cisek vd, 2014: 1). Böylece narsist bireyler, kişiliklerinden dolayı lüks ve gösterişçi markalar tüketmekte, tükettikçe de narsist kişilikleri güçlenmektedir (Sedikides vd, 2007/2013).

\subsection{Narsisizm ile Lüks Tüketim İlişkisi}

Kökeni Latince "luxuria" kelimesine dayanan; "aşırı", "fazlalık" ve "ekstra" anlamlarında kullanılan lüks kavramının (Danziger, 2004) tanımı konusunda hala fikir birliği bulunmamaktadır. Bunun yanı sıra kavram genellikle yaşam gereksinimlerinin ötesinde nadir, deneyimler ve hedonik duygular anlamına gelmektedir (Kapferer, Klippert ve Leproux, 2013: 2). Heine (2012) ise bu kavramı yüksek fiyatlı, nadir bulunan, statü sağlayan, arzu edilen ve sıradan olmayan olarak tanımlarken (46-62), lüks literatür çalışmalarında göreceli olarak kabul edilmektedir (Oransay, 2017: 43; Dogan vd, 2020; (Kapferer, Klippert ve Leproux, 2013: 2). Ayrıca lüks kavramı, sadece kişiden kişiye değil, kültürden kültüre de değişiklik 
göstermektedir. Hatta tüketicilerin lüks markaları satın alma sebeplerinde de kültürün etkisi bulunmaktadır. Örneğin Wong ve Ahuvia'nın (1998) yapmış olduğu çalışmaya göre, bireysel kültüre sahip bireyler lüks markaları kendilerini ifade etmek için, kolektif kültüre sahip bireyler ise sosyal ihtiyaçlarından dolayı satın almaktadır.

Lüks markalar, olağanüstü kalite, işçilik, benzersizlik, el yapımı, nadirlik, prestij ve asil gibi yönlerini vurgulamaktadır. Bu sebeple tüketiciler de münhasırlık, hedonizm, nadir kaliteye erişim, özgünlük ve deneyimlerden dolayı lüks markalara yönelmektedir (Yeoman, 2011: 48; Kapferer, Klippert ve Leproux, 2013: 3; Oransay, 2017). Diğer bir deyişle tüketiciler, kendilerine yüklemek istedikleri anlamlardan ve farklılaşabilme isteğinden dolayı lüks markaları kullanmakta (Hürmeriç ve Baban, 2012: 91) ve marka ne kadar nadirse tüketici o kadar çok satın alma davranışı göstermektedir. $\mathrm{Bu}$ bağlamda marka, nadirliği ve benzersizliğiyle ilgili imajını kaybettikçe, tüketicinin ilgisini de kaybedeceği söylenebilir. Zhan ve He'nin (2012) araştırmasına göre de diğerlerinden farklı olmak isteyen tüketiciler lüks markalar hakkında fazla bilgi edindikçe, o marka hakkında olumsuz duygular beslemekte ve satın almayı tercih etmemektedir. Bu sebeple tüketicilerin rasyonel özelliğinden ziyade, yaşattığı pozitif duygular için lüks markaları tercih ettikleri söylenebilir. Ayrıca lüks markaların statü ve prestij sağladığı da bilinmektedir (Kapferer, 2010). Lüks markaların tüketicilere güçlü sembolik değerler yüklemesinin sebebi olarak ürünlerin fiyatının yüksek olması, ürünlerin her yerde satılmaması ve sınırlı sayıda bulunması da gösterilebilir. Çünkü tüketici sınırlı sayıda olan, ulaşılması zor olan lüks markaların ürünlerini kullanarak kendisini özel ve ayrıcalıklı hissetmektedir (Maden, 2014: 21-31; Tığlı ve Akyazgan, 2003). Amaldoss ve Jain'in (2005) yapmış olduğu araştırmaya göre, benzersiz olmak isteyen tüketiciler, bir ürünün fiyatı arttıkça daha çok satın alma davranışı sergilemektedir. Diğer bir deyişle tüketiciler lüks markalarla ilişki kurarak elde edecekleri psikolojik faydalara önem vermektedir. Tüketiciler, lüks markaların imajlarını kendi imajları için kullanabilmekte ve kendileri için oluşturdukları imajları başkalarına sunabilmektedir (Escalas ve Bettman, 2003).

Yukarıdaki bilgiler 1şığında narsist kişilik özelliğine sahip bireylerin, lüks marka tüketimleri arasında ilişki olabileceği düşünülmektedir. Bunun sebebi narsist olan ve olmayan bireylerin markalara olan yönelimleri incelendiğinde, narsist bireylerin daha bireyselci olduğu görülmektedir. Ayrıca narsist kişiler, olmayanlara oranla daha fazla yüksek statüye sahip markalara yönelmektedir. Bu bağlamda narsisizm ile tüketim arasında bir bağlantı olduğu söylenebilir (Lambert ve Desmond, 2013). Ayrıca tüketime önem veren bireylerin, lüks markalar aracılığıyla sosyal kimliklerini yansıtıp, göstermek istedikleri de bilinmektedir. Çünkü maddiyata önem veren bireyler, lüks markaları imajlarının önemli bir parçası olarak görmekte ve böylece markayı kullanmak için motive olmaktadır (Belk, 1984). Diğer bir deyişle aşırı, fazla tüketim, lüks tüketim, gösterişçi tüketim ve yüksek materyalizm ile kişilerdeki narsisizmle ilgili bir ilişkinin olduğu görülmektedir (Mcdonald, Wearing ve Ponting, 2007; Cisek vd, 2014). Bunlara ek olarak başkalarıla benzer olduklarının algılanmasından korkan ve bu durumu kendi kimliklerine yönelik bir tehdit olarak algılayan bireyler (Snyder ve Fromkin, 1977), kendilerini diğerlerinden ayırmak için benzersiz ürünler edinme çabasına girmektedir (Snyder, 1992). Bu durum da bireyleri lüks markalara yönlendirmektedir. $\mathrm{Bu}$ bilgilere ek olarak narsist kişilik özelliklerine sahip bireylerin başkalarından tavsiye almadıkları, eşsiz ürünler satın almak istedikleri ve savurganca davranıp, plansız satın alma davranışı sergiledikleri bilinmektedir (Aytaç, 2019: 117-118). Kang ve Park'nın (2016) narsisizm ile lüks tüketim arasındaki ilişkiye dair yapmış oldukları çalışmaya göre de gizli narsist kişilik özelliklerine sahip olan bireyler büyük logolu ürünleri 
satın alırken, açık narsist kişiliğine sahip bireyler ise kişiye özel, özgün ürünleri tercih etmektedir. Bu bağlamda, haz arayışında olan ve tüketerek mutlu olacağını düşünen bireylerde narsistlik eğiliminin fazla olduğu söylenebilir. Bunun sebebi zevkine düşkün, haz arayışındaki tüketicilerin bencil davranışlar sergiledikleri görülmektedir (Dal, 2017: 16). Bu bilgiler 1şığında narsist kişilik özelliklerine sahip bireylerin lüks markalara olan eğilimlerinin yüksek oldukları varsayımı yapılabilir.

\section{ARAŞTIRMANIN YÖNTEMI}

\subsection{Araştırmanın Amacı, Kısıtları, Türü ve Hipotezleri}

Kişilerde bencil davranışlar, gösterişçi tutumlar, üstünlük anlayışının oluşmasına sebep olan narsisizm; insanların yaşamlarını, çevresindekilerle olan ilişkilerini etkilemenin yanı sıra tüketim davranışlarında da büyük rol oynamaktadır. Çevresindekilere kendilerini göstermek ve üstün olmak isteyen narsist kişiler, kullandıkları ürünlerde de benzer tutumlar göstermektedir. Bu bağlamda çalışmanın amacı; narsist eğilim gösteren kişilerle, lüks tüketim eğilimleri arasında bir ilişkinin olup olmadığının irdelenmesidir. Ayrıca çalışmada, narsist eğilimin alt boyutu olan hayranlık ve rekabet ile tüketicilerin lüks tüketim eğilimleri arasında bir ilişki olup olmadı̆̆ incelenmektedir.

Aşağıda yer alan hipotezler Cisek ve arkadaşlarının (2014), Audrin vd. (2017), Karaaziz ve Atak'ın (2013), Kang ve Park'ın (2016), Dogan ve arkadaşlarının (2020), Harnis ve Bridges'ın (2015), Demirci ve Ekşi'nin (2017) ve Yazıcı'nın (2019) çalışmalarından yararlanılarak hazırlanmıştır:

Hipotez 1: Katılımcıların narsisizmi ile lüks tüketim eğilimleri arasında anlamlı bir ilişki vardır.

Hipotez 1a: Katılımcıların narsisizmin alt boyutu olan hayranlık ile lüks tüketim eğilimleri arasında anlamlı bir ilişki vardır.

Hipotez 1b: Katılımcıların narsisizmin alt boyutu olan rekabet ile lüks tüketim eğilimleri arasında anlamlı bir ilişki vardır.

\subsection{Araştırma Metodolojisi}

Araştırmada, bilgi ve verilerin kolay toplanabilmesinden dolayı, "kolayda örnekleme" yöntemi (Kurtuluş, 2010: 63) tercih edilmektedir. Bu bağlamda araştırmanın ana kütlesini, zaman ve maliyet kısıtlamasından dolayı sadece İstanbul'da bulunan Marmara Üniversitesi öğrencileri oluşturmaktadır. Ayrıca katılımcıların narsisizmini belirlemek için kullanılan Demir ve Ekşi'nin (2017) ölçeğinin de Marmara Üniversitesi’nde geliştirilmiş olması, çalışmanın bu üniversitede yapılmasını belirleyen bir diğer etkendir. Araştırmanın sadece Marmara Üniversitesi öğrencileriyle gerçekleştirilmesinden dolayı, çalışmanın sonuçlarının Türkiye çapında genellemesi yapılamaz. Ayrıca bu araştırmadaki gibi problem çözümüne yönelik yapılan çalışmalarda genellikle örnek hacminin 300 'le 500 kişi arasında gerçekleşmesi (Naresh ve Birks, 2000: 351) gerektiği için çalışmada 430 kişiye anket uygulanmıştır. Fakat yapılan anketler sonucunda güvenilir bulunmayan 93 kişi elenmiş olup, çalışmada 337 kişilik bir örneklem hacmine ulaşılmıştır. 
Araştırmanın amacı katılımcıların narsist kişilikleri ile lüks tüketim eğilimleri arasındaki ilişkiyi incelemektedir. Bu bağlamda araştırmada veri toplama amacıyla uygulanan anket formu üç bölümden oluşmaktadır. $\mathrm{Bu}$ bölümlerden ilkinde katılımcıların narsisizm eğilimlerini irdelenmekteyken, formun ikinci bölümde ise ankete katılanların lüks tüketim eğilimleri incelenmektedir. Araştırmanın son bölümünde ise katılımcıların demografik özelliklerine ve değerlendirmelerine ilişkin sorular bulunmaktadır. Araştırmada tüketicilerin narsisizm eğilimlerini ölçmek için Demirci ve Ekşi'nin (2017) "Narsistik Hayranlık ve Rekabet Ölçeği'nin" Türkçeye uyarlayıp daha sonra psikometrik özelliklerini inceledikleri "Büyüklenmeci narsisizmin iki farklı yüzü: hayranlık ve rekabetin mutlulukla ilişkisi" adlı çalışmasından yararlanılmıştır. Bununla birlikte katılımcıların lüks tüketim eğilimlerini irdelemek amacıyla Dogan, Ozkara ve Dogan'ın (2020) çalışması kullanılmıştır. Böylece katılımcıların narsist kişilikleri ve narsist kişiliğin alt boyutu olan hayranlık ve rekabet faktörünün, lüks tüketim eğilimleri arasında ilişki olup olmadığı irdelenmiştir. Bu bağlamda, ölçekte yer alan her bir kategori beşli skala üzerinden değerlendirilmiştir.

\subsection{Verilerin İstatistiksel Analizi}

Araştırmada katılımcılardan elde edilen veriler amaca uygun istatistik paket programı aracılığıyla analiz edilmiştir. Araştırmada tanımlayıcı istatistiksel yöntemleri olarak "sayı", "yüzde", "ortalama" ve "standart sapma" kullanılarak veriler değerlendirilmiştir. Sürekli değişkenler arasında ise "Pearson Korelasyon" ve "Regresyon" analizler uygulanmıştır. Ölçeklerin güvenirliğini de ölçülmüş olup, narsisizm ölçeğinin Cronbach's Alpha’sı 0.799 ve lüks tüketim eğilimi ölçeğinin Cronbach's Alpha'sı 0.897 olarak ikisi de yüksek bulunmuştur.

\subsection{Bulgular ve Yorumlar}

Araştırmada bulunan verilerin analizleri ve bu analizlerin yorumları yer almaktadır. Tablo 1'de katılımcıların demografik özelliklerine dair bilgiler yer almaktadır.

\begin{tabular}{lcc}
\multicolumn{2}{c}{$\begin{array}{c}\text { Tablo 1. Katılımcıların Tanımlayıcı Özellikleri } \\
\text { Gruplar }\end{array}$} & $\begin{array}{l}\text { Frekans(n) } \\
\text { Yüzde (\%) }\end{array}$ \\
\hline Cinsiyet & 208 & 61.7 \\
\hline Erkek & 129 & 38.3 \\
\hline Kadın & & \\
\hline Yaş & 247 & 73.3 \\
\hline 25 ve altı & 90 & 26.7 \\
\hline 25 ve üzeri & \\
\hline Eğitim Durumu & 29 & 8.6 \\
\hline Ön lisans & 196 & 58.2 \\
\hline Lisans & 112 & 33.2 \\
\hline Lisansüstü & & \\
\hline Medeni Durum & 50 & 14.8 \\
\hline Evli & 287 & 85.2 \\
\hline Bekar & & \\
\hline Çalıșma Durumu & 127 & 37.7 \\
\hline Evet & 210 & 62.3 \\
\hline Hayır &
\end{tabular}

Aylık Gelir 


\begin{tabular}{lcc}
1000 TL ve alt1 & 163 & 48.4 \\
\hline $1001-2000 \mathrm{TL}$ & 78 & 23.1 \\
\hline 2000TL ve üzeri & 96 & 28.5 \\
\hline Aile Toplam Aylık Gelir & & \\
\hline $5000 \mathrm{TL}$ ve alt1 & 161 & 47.8 \\
\hline 5001-10000TL & 127 & 37.7 \\
\hline $10000 \mathrm{TL}$ ve üzeri & 49 & 14.5
\end{tabular}

Katılımcılar cinsiyetlerine göre 208'i (\%61.7) erkek ve 129'u (\%38.3) kadın olarak dağılmaktadır. Yaş değişkenleri incelendiğinde ise katılımcıların 247'si (\%73.3) 25 ve altı, 90'1 (\%26.7) ise 25 ve üzeri olduğu tespit edilmiştir. Katılımcıların öğretim seviyesi irdelendiğinde ise 29'u (\%8.6) ön lisans, 196's1 (\%58.2) lisans, 112'si (\%33.2) ise lisansüstü eğitimi görmektedir. Ayrıca katılımcıların medeni durumları da incelenmiş ve 50'sinin (\%14.8) evli, 287'sinin (\%85.2) ise bekar olduğu tespit edilmiştir. Katılımcıların aktif iş yaşamında olup olmadığı da sorulmuş, katılımcıların 127'sinin (\%37.7) çalıştığı, 210'unun (\%62.3) ise çalışmadığı görülmektedir. Bunun yanı sıra katılımcıların gelir durumları incelendiğinde 163'ü (\%48.4) 1000 TL ve altı, 78'i (\%23.1) 1001-2000 TL arasında ve 96's1 (\%28.5) 2000 TL ve üzeri olarak dağılmaktadır. Ayrıca katılımcılar aile toplam aylık gelir göre 161'i (\%47.8) 5000TL ve alt1, 127'si (\%37.7) 5001-10000TL, 49'u (\%14.5) 10000 TL ve üzeri olarak dağılmaktadır.

Tablo 2. Narsisizm İle Lüks Tüketim Eğilimi Puan Ortalamaları

\begin{tabular}{lccccc} 
& N & Ort & Ss & Min. & Max. \\
\hline Büyüklenme & 337 & 2.876 & 0.846 & 1.000 & 5.000 \\
\hline Benzersizlik & 337 & 3.252 & 0.870 & 1.000 & 5.000 \\
\hline Cazibe & 337 & 3.046 & 0.841 & 1.000 & 5.000 \\
\hline Saldırganlık & 337 & 2.335 & 0.860 & 1.000 & 5.000 \\
\hline Üstünlük & 337 & 1.998 & 0.936 & 1.000 & 5.000 \\
\hline Değersizleştirme & 337 & 1.629 & 0.731 & 1.000 & 5.000 \\
\hline Narsisizm Genel & 337 & 2.523 & 0.536 & 1.170 & 4.280 \\
\hline Hayranlık & 337 & 3.058 & 0.681 & 1.220 & 5.000 \\
\hline Rekabet & 337 & 1.988 & 0.627 & 1.000 & 4.440 \\
\hline Ürün Benzersizliği & 337 & 3.114 & 1.036 & 1.000 & 5.000 \\
\hline Pahalılı & 337 & 2.119 & 0.801 & 1.000 & 4.750 \\
\hline Sembolik Anlam & 337 & 2.170 & 0.929 & 1.000 & 4.750 \\
\hline Keyfi Arzu & 337 & 2.239 & 1.067 & 1.000 & 5.000 \\
\hline $\begin{array}{l}\text { Münhazır Bir Azınlığa Ait } \\
\text { Olmak }\end{array}$ & 337 & 2.219 & 1.111 & 1.000 & 5.000 \\
\hline Lüks Tüketim Ĕ̈ilimi Genel & 337 & 2.388 & 0.726 & 1.110 & 4.440
\end{tabular}

Araştırmada kullanılan narsisizm ölçeği "hayranlık" ve "rekabet" adlı altında iki faktöre ayrılmaktadır. Bu iki faktör de kendi içinde alt boyutlara sahiptir. Hayranlık adlı faktör "büyüklenme", "benzersizlik" ve "cazibe" adlı boyutlara; rekabet ise "saldırganlık", "üstünlük" ve "değersizleştirme" adı altında ayrılmaktadır. Ayrıca araştırmada kullanılan lüks tüketim eğilim ölçeği ise "ürün benzersizliği”, "pahalılık", "sembolik anlam", "keyfi arzu” ve "münhazır bir azınlığa ait olmak" adlı beş alt boyuta sahiptir. Elde edilen verilere göre katılımcıların "büyüklenme" ortalaması orta 2.876 \pm 0.846 (Min=1; Maks=5), "benzersizlik" 
ortalamas1 orta $3.252 \pm 0.870$ (Min=1; Maks=5), "cazibe" ortalamas1 orta $3.046 \pm 0.841$ (Min=1; Maks=5), "saldırganlık" ortalaması zayıf 2.335 \pm 0.860 (Min=1; Maks=5), "üstünlük" ortalaması zayıf $1.998 \pm 0.936$ (Min=1; Maks=5), "değersizleştirme" ortalaması çok zayıf $1.629 \pm 0.731(\mathrm{Min}=1 ; \mathrm{Maks}=5)$, "narsisizm genel" ortalaması zayıf 2.523 $\pm 0.536(\mathrm{Min}=1.17$; Maks=4.28), "hayranl1k" ortalamas1 orta 3.058 \pm 0.681 (Min=1.22; Maks=5), "rekabet" ortalaması zayıf $1.988 \pm 0.627$ (Min=1; Maks=4.44), "ürün benzersizliği” ortalamas1 orta $3.114 \pm 1.036$ (Min=1; Maks=5), "pahalılık" ortalaması zayıf 2.119 \pm 0.801 (Min=1; Maks=4.75), "sembolik anlam" ortalaması zayıf 2.170 \pm 0.929 (Min=1; Maks=4.75), "keyfi arzu" ortalaması zayıf 2.239 \pm 1.067 (Min=1; Maks=5), "münhazır bir azınlığa ait olmak" ortalaması zayıf 2.219 \pm 1.111 (Min=1; Maks=5), "lüks tüketim eğilimi genel” ortalaması zayıf $2.388 \pm 0.726$ (Min=1.11; Maks=4.44), olarak saptanmıştır.

\section{Tablo 3. Narsisizm İle Lüks Tüketim Eğilimi Puanları Arasında Korelasyon Analizi}

\begin{tabular}{|c|c|c|c|c|c|c|c|c|c|c|}
\hline & & 章 & 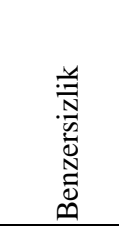 & 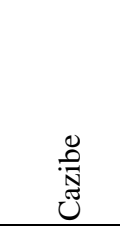 & 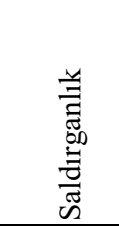 & 兰 & 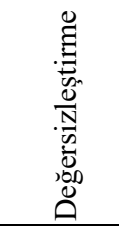 & 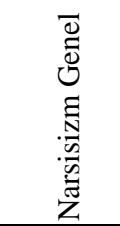 & 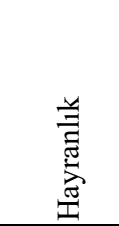 & 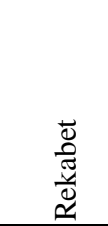 \\
\hline & $\mathrm{p}$ & 0.000 & 0.000 & 0.000 & 0.000 & 0.000 & 0.000 & 0.000 & 0.000 & 0.000 \\
\hline \multirow{2}{*}{$\begin{array}{l}\text { Ürün } \\
\text { Benzersizliği }\end{array}$} & $\mathrm{r}$ & $0.113 *$ & $0.225 * *$ & $0.143 * *$ & $0.212 * *$ & $0.257 * *$ & $0.146^{* *}$ & $0.292 * *$ & $0.202 * *$ & $0.281 * *$ \\
\hline & $\mathrm{p}$ & 0.038 & 0.000 & 0.009 & 0.000 & 0.000 & 0.007 & 0.000 & 0.000 & 0.000 \\
\hline \multirow{2}{*}{ Pahalılık } & $\mathrm{r}$ & 0.090 & $0.149 * *$ & 0.084 & 0.097 & 0.039 & $0.205 * *$ & $0.170 * *$ & $0.135^{*}$ & $0.143 * *$ \\
\hline & $\mathrm{p}$ & 0.100 & 0.006 & 0.126 & 0.075 & 0.472 & 0.000 & 0.002 & 0.013 & 0.008 \\
\hline \multirow{2}{*}{$\begin{array}{l}\text { Sembolik } \\
\text { Anlam }\end{array}$} & $\mathrm{r}$ & $0.201 * *$ & $0.247 * *$ & $0.169 * *$ & $0.306 * *$ & $0.175 * *$ & $0.190 * *$ & $0.340 * *$ & $0.258 * *$ & $0.301 * *$ \\
\hline & $\mathrm{p}$ & 0.000 & 0.000 & 0.002 & 0.000 & 0.001 & 0.000 & 0.000 & 0.000 & 0.000 \\
\hline \multirow{2}{*}{ Keyfi Arzu } & $\mathrm{r}$ & $0.244 * *$ & $0.216^{* *}$ & $0.157 * *$ & $0.219 * *$ & $0.113^{*}$ & $0.178 * *$ & $0.296 * *$ & $0.258 * *$ & $0.225 * *$ \\
\hline & $\mathrm{p}$ & 0.000 & 0.000 & 0.004 & 0.000 & 0.038 & 0.001 & 0.000 & 0.000 & 0.000 \\
\hline \multirow{2}{*}{$\begin{array}{l}\text { Münhazır } \\
\text { Bir Azınlığa } \\
\text { Ait Olmak }\end{array}$} & $\mathrm{r}$ & $0.142 * *$ & $0.176^{* *}$ & 0.080 & $0.276 * *$ & $0.360 * *$ & $0.325 * *$ & $0.358 * *$ & $0.166 * *$ & $0.432 * *$ \\
\hline & $\mathrm{p}$ & 0.009 & 0.001 & 0.143 & 0.000 & 0.000 & 0.000 & 0.000 & 0.002 & 0.000 \\
\hline \multirow{2}{*}{$\begin{array}{l}\text { Lüks } \\
\text { Tüketim } \\
\text { Eğilimi } \\
\text { Genel }\end{array}$} & $\underline{r}$ & $0.211 * *$ & $0.276 * *$ & $0.173 * *$ & $0.302 * *$ & $0.260 * *$ & $0.277 * *$ & $0.395 * *$ & $0.276 * *$ & $0.375^{* *}$ \\
\hline & & 0.000 & 0.000 & 0.001 & 0.000 & 0.000 & 0.000 & 0.000 & 0.000 & 0.000 \\
\hline
\end{tabular}

Katılımcıların "narsisizm" ile "lüks tüketim eğilimi” arasında pozitif korelasyonlar olduğu görülmektedir. Diğer bir deyişle, yukarıdaki korelasyon analizi tablosuna göre, narsisizm ve lüks tüketim eğilimi ve değişkenlerin alt boyutları arasında ilişki olduğu saptanmıştır. Tablodaki verilere göre ürün benzersizliği ile büyüklenme arasında $\mathrm{r}=0.113$ pozitif $(\mathrm{p}=0.000<0.05)$, ürün benzersizliği ile benzersizlik arasında $\mathrm{r}=0.225$ pozitif $(\mathrm{p}=0.000<0.05)$, ürün benzersizliği ile cazibe arasında $\mathrm{r}=0.143$ pozitif $(\mathrm{p}=0.000<0.05)$, ürün benzersizliği ile saldırganlık arasında $\mathrm{r}=0.212$ pozitif $(\mathrm{p}=0.000<0.05)$, ürün benzersizliği ile üstünlük arasında $\mathrm{r}=0.257$ pozitif $(\mathrm{p}=0.000<0.05)$, ürün benzersizliği ile değersizleştirme arasında $\mathrm{r}=0.146$ pozitif $(\mathrm{p}=0.000<0.05)$, ürün benzersizliği ile narisisizm arasında $\mathrm{r}=0.292$ pozitif $(\mathrm{p}=0.000<0.05)$, ürün benzersizliği ile hayranlık arasında $\mathrm{r}=0.202$ pozitif $(\mathrm{p}=0.000<0.05)$, 
ürün benzersizliği ile rekabet arasında $\mathrm{r}=0.281$ pozitif $(\mathrm{p}=0.000<0.05)$ 'dir. Pahalılık ile benzersizlik arasında $\mathrm{r}=0.149$ pozitif $(\mathrm{p}=0.000<0.05)$, pahalılık ile değersizleştirme arasında $\mathrm{r}=0.205$ pozitif $(\mathrm{p}=0.000<0.05)$, pahalılık ile narisisizm arasında $\mathrm{r}=0.170$ pozitif $(\mathrm{p}=0.000<0.05)$, pahalılık ile hayranlık arasında $\mathrm{r}=0.135$ pozitif $(\mathrm{p}=0.000<0.05)$, pahalılık ile rekabet arasında $\mathrm{r}=0.143$ pozitif $(\mathrm{p}=0.000<0.05)$ 'dir. Sembolik anlam ile büyüklenme arasında $r=0.201$ pozitif $(\mathrm{p}=0.000<0.05)$, sembolik anlam ile benzersizlik arasında $\mathrm{r}=0.247$ pozitif $(p=0.000<0.05)$, sembolik anlam ile cazibe arasında $r=0.169$ pozitif $(p=0.000<0.05)$, sembolik anlam ile saldırganlık arasında $\mathrm{r}=0.306$ pozitif $(\mathrm{p}=0.000<0.05)$, sembolik anlam ile üstünlük arasında $\mathrm{r}=0.175$ pozitif $(\mathrm{p}=0.000<0.05)$, sembolik anlam ile değersizleştirme arasında $\mathrm{r}=0.190$ pozitif $(\mathrm{p}=0.000<0.05)$, sembolik anlam ile narisisizm arasında $\mathrm{r}=0.340$ pozitif $(\mathrm{p}=0.000<0.05)$, sembolik anlam ile hayranlık arasında $\mathrm{r}=0.258$ pozitif $(\mathrm{p}=0.000<0.05)$, sembolik anlam ile rekabet arasında $\mathrm{r}=0.301$ pozitif $(\mathrm{p}=0.000<0.05)$ 'dir. Keyfi arzu ile büyüklenme arasında $\mathrm{r}=0.244$ pozitif $(\mathrm{p}=0.000<0.05)$, keyfi aruz ile benzersizlik arasinda $\mathrm{r}=0.216$ pozitif $(\mathrm{p}=0.000<0.05)$, keyfi arzu ile cazibe arasinda $\mathrm{r}=0.157$ pozitif $(\mathrm{p}=0.000<0.05)$, keyfi arzu ile saldirganlık arasında $\mathrm{r}=0.219$ pozitif $(\mathrm{p}=0.000<0.05)$, keyfi arzu ile üstünlük arasında $\mathrm{r}=0.113$ pozitif $(\mathrm{p}=0.000<0.05)$, keyfi aruz ile değersizleştirme arasında $\mathrm{r}=0.178$ pozitif $(\mathrm{p}=0.000<0.05)$, keyfi arzu ile narisisizm arasında $\mathrm{r}=0.296$ pozitif $(\mathrm{p}=0.000<0.05)$, keyfi arzu ile hayranlık arasında $\mathrm{r}=0.258$ pozitif $(\mathrm{p}=0.000<0.05)$, keyfi arzu ile rekabet arasında $\mathrm{r}=0.225$ pozitif $(\mathrm{p}=0.000<0.05)$ 'dir. Münhazır bir azınlığa ait olmak ile büyüklenme arasında $\mathrm{r}=0.142$ pozitif $(\mathrm{p}=0.000<0.05)$, münhazır bir azınlığa ait olmak ile benzersizlik arasında $\mathrm{r}=0.176$ pozitif $(\mathrm{p}=0.000<0.05)$, münhazır bir azınlığa ait olmak ile saldırganlık arasında $\mathrm{r}=0.276$ pozitif $(\mathrm{p}=0.000<0.05)$, münhazır bir azınlığa ait olmak ile üstünlük arasında $\mathrm{r}=0.360$ pozitif $(\mathrm{p}=0.000<0.05)$, münhazır bir azınlığa ait olmak ile değersizleştirme arasında $\mathrm{r}=0.325$ pozitif $(\mathrm{p}=0.000<0.05)$, münhazır bir azınlığa ait olmak ile narisisizm arasında $\mathrm{r}=0.358$ pozitif $(\mathrm{p}=0.000<0.05)$, münhazır bir azınlığa ait olmak ile hayranlık arasında $\mathrm{r}=0.166$ pozitif $(\mathrm{p}=0.000<0.05)$, münhazır bir azınlığa ait olmak ile rekabet arasında $\mathrm{r}=0.432$ pozitif $(\mathrm{p}=0.000<0.05)$ 'dir. Lüks tüketim eğilimi genel ile büyüklenme arasında $\mathrm{r}=0.211$ pozitif $(\mathrm{p}=0.000<0.05)$, lüks tüketim eğilimi genel ile benzersizlik arasında $\mathrm{r}=0.276$ pozitif $(\mathrm{p}=0.000<0.05)$, lüks tüketim eğilimi genel ile cazibe arasında $\mathrm{r}=0.173$ pozitif $(\mathrm{p}=0.000<0.05)$, lüks tüketim eğilimi genel ile saldırganlık arasında $\mathrm{r}=0.302$ pozitif $(\mathrm{p}=0.000<0.05)$, lüks tüketim eğilimi genel ile üstünlük arasında $\mathrm{r}=0.260$ pozitif $(\mathrm{p}=0.000<0.05)$, lüks tüketim eğilimi genel ile değersizleştirme arasında $\mathrm{r}=0.277$ pozitif $(\mathrm{p}=0.000<0.05)$, lüks tüketim eğilimi genel ile narisisizm arasında $\mathrm{r}=0.395$ pozitif $(\mathrm{p}=0.000<0.05)$, lüks tüketim eğilimi genel ile hayranlık arasında $\mathrm{r}=0.276$ pozitif $(\mathrm{p}=0.000<0.05)$, lüks tüketim eğilimi genel ile rekabet arasında $\mathrm{r}=0.375$ pozitif $(\mathrm{p}=0.000<0.05)^{\prime}$ 'dir.

Tablo 4. Narsisizm İle Lüks Tüketim Eğilimi İlişkisi

\begin{tabular}{|c|c|c|c|c|c|c|c|}
\hline Bağımlı Değişken & Bağımsız Değişken & $\beta$ & $\mathrm{t}$ & $\mathrm{p}$ & $\mathrm{F}$ & $\begin{array}{l}\text { Mode } \\
1(\mathrm{p})\end{array}$ & $\mathrm{R}^{2}$ \\
\hline \multirow{2}{*}{$\begin{array}{l}\text { Lüks tüketim } \\
\text { eğilimi genel }\end{array}$} & Sabit & 1.040 & 5.931 & 0.000 & \multirow{2}{*}{-61.806} & \multirow{2}{*}{0.000} & \multirow{2}{*}{0.153} \\
\hline & Narsisizm Genel & 0.534 & 7.862 & 0.000 & & & \\
\hline \multirow{3}{*}{$\begin{array}{l}\text { Lüks tüketim } \\
\text { eğilimi genel }\end{array}$} & Sabit & 1.112 & 6.232 & 0.000 & \multirow{3}{*}{33.081} & \multirow{3}{*}{0.000} & \multirow{3}{*}{0.160} \\
\hline & Hayranlık & 0.178 & 3.138 & 0.002 & & & \\
\hline & Rekabet & 0.368 & 5.972 & 0.000 & & & \\
\hline \multirow{2}{*}{$\begin{array}{l}\text { Lüks tüketim } \\
\text { eğilimi genel }\end{array}$} & Sabit & 1.017 & 5.561 & 0.000 & \multirow{2}{*}{-12.632} & \multirow{2}{*}{0.000} & \multirow{2}{*}{0.172} \\
\hline & Büyüklenme & -0.028 & -0.473 & 0.637 & & & \\
\hline
\end{tabular}




\begin{tabular}{|c|c|c|c|c|c|c|c|}
\hline & Benzersizlik & 0.175 & 3.105 & 0.002 & & & \\
\hline & Cazibe & 0.028 & 0.588 & 0.557 & & & \\
\hline & Saldırganlık & 0.141 & 2.832 & 0.005 & & & \\
\hline & Üstünlük & 0.056 & 1.230 & 0.220 & & & \\
\hline & Değersizleştirme & 0.219 & 4.160 & 0.000 & & & \\
\hline \multirow{3}{*}{ Ürün benzersizliği } & Sabit & 1.771 & 6.666 & 0.000 & \multirow{3}{*}{16.835} & \multirow{3}{*}{0.000} & \multirow{3}{*}{0.086} \\
\hline & Hayranlık & 0.181 & 2.148 & 0.032 & & & \\
\hline & Rekabet & 0.397 & 4.326 & 0.000 & & & \\
\hline \multirow{3}{*}{ Pahalılık } & Sabit & 1.490 & 7.013 & 0.000 & \multirow{3}{*}{4.970} & \multirow{3}{*}{0.007} & \multirow{3}{*}{0.023} \\
\hline & Hayranlık & 0.114 & 1.691 & 0.092 & & & \\
\hline & Rekabet & 0.141 & 2.155 & 0.046 & & & \\
\hline \multirow{3}{*}{ Sembolik anlam } & Sabit & 0.728 & 3.101 & 0.002 & \multirow{3}{*}{22.290} & \multirow{3}{*}{0.000} & \multirow{3}{*}{0.112} \\
\hline & Hayranlık & 0.240 & 3.211 & 0.001 & & & \\
\hline & Rekabet & 0.357 & 4.396 & 0.000 & & & \\
\hline \multirow{3}{*}{ Keyfi arzu } & Sabit & 0.734 & 2.680 & 0.008 & \multirow{3}{*}{16.061} & \multirow{3}{*}{0.000} & \multirow{3}{*}{0.082} \\
\hline & Hayranlık & 0.320 & 3.676 & 0.000 & & & \\
\hline & Rekabet & 0.264 & 2.790 & 0.006 & & & \\
\hline \multirow{3}{*}{$\begin{array}{l}\text { Münhazır bir } \\
\text { azınlığa ait olmak }\end{array}$} & Sabit & 0.620 & 2.301 & 0.022 & \multirow{3}{*}{38.311} & \multirow{3}{*}{0.000} & \multirow{3}{*}{0.182} \\
\hline & Hayranlık & 0.034 & 0.395 & 0.693 & & & \\
\hline & Rekabet & 0.752 & 8.078 & 0.000 & & & \\
\hline
\end{tabular}

Araştırmada narsisizm genel puanı ile lüks tüketim eğilimi genel puanı arasındaki neden ve sonuç ilişkisini bulmak için gerçekleştirilen regresyon adlı analizin sonucu anlamlı çıkmıştır $(\mathrm{F}=61.806 ; \mathrm{p}=0.000<0.05)$. Bu bağlamda lüks tüketim eğilimi düzeyindeki toplam değişim $\% 15.3$ oranında narsisizm genel puanı tarafından açıklanmaktadır $\left(\mathrm{R}^{2}=0.153\right)$. Bu durumunda narsisizm genel puanı, lüks tüketim eğilimini arttırdığı görülmektedir $(\beta=0.534)$. Diğer bir deyişle, katılımcıların sahip olduğu narsist kişilik özelliklerinin, lüks tüketime eğilim göstermelerinde etkili olduğu varsayılmaktadır. Bu bağlamda elde edilen bulgular; hipotez 1'i desteklenmektedir. Çalışmada narsisizmin alt boyutlarından olan "hayranlık" ve "rekabet" faktörü ile lüks tüketim eğilimi genel arasındaki neden ve sonuç ilişkisini bulmak için gerçekleştirilen regresyon adlı analizin sonucu anlamlı çıkmıştır ( $\mathrm{F}=33.081$; $\mathrm{p}=0.000<0.05)$. Lüks tüketim eğilimi genel düzeyindeki toplam değişim $\% 16$ oranında hayranlık ve rekabet faktörleri tarafından açıklanmaktadır $\left(\mathrm{R}^{2}=0.160\right)$. Elde edilen bulgulara göre narsisizmin alt boyutlarından olan hayranlık faktörü, lüks tüketim eğilimi genel düzeyini arttırmaktadır $(\beta=0.178)$. $\mathrm{Bu}$ bağlamda, katılımcıların "narsisizminin alt boyutu olan hayranlık ile lüks tüketim eğilimleri arasında anlamlı bir ilişki vardır” hipotez 1a'sı desteklenmektedir. Ayrıca elde edilen bulgular 1şığında narsisizminin alt boyutu olan rekabet faktörünün de katılımcıların lüks tüketim eğilimini arttırdığı görülmektedir $(\beta=0.368)$. $\mathrm{Bu}$ sebeple katılımcıların "narsisizminin alt boyutu olan rekabet faktörü ile lüks tüketim eğilimleri arasında anlamlı bir ilişki vardır" hipotezi 1b'si desteklenmektedir.

Araştırmada kullanılan ölçekte narsisizmin alt boyutlarından olan hayranlık faktörünün; "büyüklenme", "benzersizlik" ve "cazibe" adlı alt boyutları bulunmaktadır. Ayrıca narsisizmin diğer alt boyutu olan rekabet faktörünün de "saldırganlık", "üstünlük" ve "değersizleştirme" adlı boyutları vardır. Bu bağlamda yapılan araştırmalarda elde edilen veriler 1şığında; büyüklenme, benzersizlik, cazibe, saldırganlık, üstünlük, değersizleştirme ile 
lüks tüketim eğilimi genel arasındaki neden ve sonuç ilişkisini bulmak için gerçekleştirilen regresyon adlı analizin sonucu anlamlı çıkmıştır $(\mathrm{F}=12.632 ; \mathrm{p}=0.000<0.05)$. Lüks tüketim eğilimi genel düzeyindeki toplam değişim \%17.2 oranında büyüklenme, benzersizlik, cazibe, saldırganlık, üstünlük, değersizleştirme tarafından açıklanmaktadır $\left(\mathrm{R}^{2}=0.172\right)$. Fakat elde edilen bulgulara göre araştırmada kullanılan ölçeğin büyüklenme adlı boyutu, katılımcıların lüks tüketim eğilim düzeyini etkilememektedir $(\mathrm{p}=0.637>0.05)$. Diğer bir deyişle narsisizmin alt boyutlarından olan hayranlık faktörünün alt boyutu olan büyüklenmenin, katılımcıların lüks tüketim eğilimlerini etkilemediği söylenebilir. Ancak yapılan araştırmalara göre, hayranlık faktörünün alt boyutu olan benzersizlik, katılımcıların lüks tüketim eğilim düzeylerini arttırmaktadır ( $(=0.175)$. Diğer bir deyişle çalışmanın benzersizlik boyutu ile katılımcıların lüks tüketim eğilimleri arasında anlamlı bir ilişkinin olduğu varsayılmaktadır. Çalışmada elde edilen veriler 1şığında hayranlık faktörünün alt boyutu olan cazibe, lüks tüketim eğilimleri genel puan düzeyini etkilemediği görülmektedir $(\mathrm{p}=0.557>0.05)$. Bunun yanı sıra çalışmada narsisizmin alt boyutu olan rekabet faktörünün altı olan saldırganlık, lüks tüketim eğilimi genel düzeyini arttırdığı görülürken $(\beta=0.141)$, üstünlük boyutu etkilememektedir $(\mathrm{p}=0.220>0.05)$. Bu bilginin tersine rekabet faktörünün alt boyutu olan değersizleştirme ise katılımcıların lüks tüketim eğilimini arttırmaktadır ( $(=0.219)$.

Ayrıca araştırmada narsisizmin alt boyutlarından olan "hayranlık" ve "rekabet" faktörlerinin, lüks tüketim eğilim ölçeğinin alt boyutları olan "ürün benzersizliğgi”, "pahalılık”, "sembolik anlam", "keyfi arzu" ve "münhazır bir azınlığa ait olmak" faktörleri arasındaki ilişki de incelenmiştir. Bu bağlamda narsisizmin alt boyutlarından olan hayranlık ve rekabet faktörleriyle, lüks tüketim eğilim alt boyutu olan ürün benzersizliği arasındaki neden ve sonuç ilişkisini bulmak için gerçekleştirilen regresyon adlı analizin sonucu anlamlı çıkmıştır $(\mathrm{F}=16.835 ; \mathrm{p}=0.000<0.05)$. Elde edilen veriler 1şığında ürün benzersizliği düzeyindeki toplam değişim \%8.6 oranında hayranlık ve rekabet tarafından açıklanmaktadır $\left(\mathrm{R}^{2}=0.086\right)$. Diğer bir deyişle, narsisizmin alt boyutu olan hayranlık, lüks tüketim eğilimi alt boyutlarından olan ürün benzersizliği düzeyini arttırmaktadır $(\beta=0.181)$. Ayrıca narsisizmin alt boyutu olan rekabet boyutu da lüks tüketim eğilimi alt boyutu olan ürün benzersizliği düzeyini de arttırmaktadır $(\beta=0.397)$. Araştırmada elde edilen veriler 1şı̆̆ında narsisizmin alt boyutlarından olan hayranlık ve rekabet faktörüyle, pahalılık arasındaki neden ve sonuç ilişkisini bulmak için gerçekleştirilen regresyon adlı analizin sonucu anlamlı çıkmıştır $(\mathrm{F}=4.970 ; \mathrm{p}=0.007<0.05)$. Çalışmada lüks tüketim eğilim alt boyutlarından olan pahalılık düzeyindeki toplam değişim \%2.3 oranında hayranlık ve rekabet tarafından açıklanmaktadır $\left(\mathrm{R}^{2}=0.023\right)$. Bu bağlamda narsisizmin alt boyutlarından olan hayranlık boyutunun lüks tüketim eğilimi alt boyutu olan pahalılık düzeyini etkilemediği görülmektedir $(p=0.092>0.05)$. Ayrıca, rekabet alt boyutunun, lüks tüketim alt boyutu olan pahalılık düzeyini arttırdığı söylenebilir $(\beta=0.141)$. Araştırmada narsisizmin alt boyutlarından olan hayranlık ve rekabet faktörü ile lüks tüketim eğilimi olan sembolik anlam boyutu arasındaki neden ve sonuç ilişkisini bulmak için gerçekleştirilen regresyon adlı analizin sonucu anlamlı çıkmıştır $(\mathrm{F}=22.290 ; \mathrm{p}=0.000<0.05)$. Elde edilen buldular, lüks tüketim alt boyutu olan sembolik anlam düzeyindeki toplam değişim \%11.2 oranında hayranlık ve rekabet faktörleri tarafından açıklanmaktadır $\left(\mathrm{R}^{2}=0.112\right)$. Hayranlık boyutu, lüks tüketim alt boyutu olan sembolik anlam düzeyini arttırmaktadır $(\beta=0.240)$. Ayrıca, rekabet boyutu lüks tüketim eğilim alt boyutu olan sembolik anlam düzeyini arttırmaktadır $(\beta=0.357)$. Çalışmada, hayranlık ve rekabet boyutu ile lüks tüketim eğilimi alt boyutu olan keyfi arzu arasındaki neden ve sonuç ilişkisini bulmak için gerçekleştirilen regresyon adlı analizin sonucu anlamlı 
çıkmıştır $(\mathrm{F}=16.061 ; \mathrm{p}=0.000<0.05)$. Elde edilen verilere göre keyfi arzu düzeyindeki toplam değişim \%8.2 oranında hayranlık, rekabet tarafından açıklanmaktadır $\left(\mathrm{R}^{2}=0.082\right)$. Narsisizmin boyutu olan hayranlık, lüks tüketim eğilimi alt boyutu olan keyfi arzu düzeyini arttırmaktadır $(\beta=0.320)$. Ayrıca rekabet boyutu, lüks tüketim eğilimi alt boyutu olan keyfi arzu düzeyini arttırmaktadır $(\beta=0.264)$. Çalışmada, narsisizminin alt boyutlarından olan hayranlık ve rekabet ile lüks tüketim eğilimi alt boyutu olan münhazır bir azınlığa ait olmak arasındaki neden ve sonuç ilişkisini bulmak için gerçekleştirilen regresyon adlı analizin sonucu anlamlı çıkmıştır $(\mathrm{F}=38.311 ; \mathrm{p}=0.000<0.05)$. Yapılan araştırmalar sonucunda münhazır bir azınlığa ait olmak düzeyindeki toplam değişim \%18.2 oranında hayranlık, rekabet tarafından açıklanmaktadır $\left(\mathrm{R}^{2}=0.182\right)$. Hayranlık alt boyutu, lüks tüketim eğilimi alt boyutu olan münhazır bir azınlığa ait olmak düzeyini etkilememektedir $(p=0.693>0.05)$. Rekabet boyutu ise, lüks tüketim alt boyutu olan münhazır bir azınlığa ait olmak düzeyini arttırmaktadir $(\beta=0.752)$.

\section{SONUÇ}

Kökeni sudaki aksine aşık olan Narkisso'a dayanan ve insanın kendisini aşırı beğenip, üstün görmesi anlamına gelen narsisizm, günümüzde dikkat çeken bir kavramdır. Narsisizm kavramı ile ilgili yapılan araştırmalar, bu eğilime sahip bireylerin kendilerini diğerlerinden daha üstün gördüğünü, teşhirci davranışlar gösterdiklerini ve gösterişçi bir tutum sergilediklerini ortaya koymaktadır. Bireylerdeki bu narsist davranışlar, marka seçimlerine ve satın alma davranışlarına da yansımaktadır. Diğer bir deyişle gösterişi seven, kendisini başkasından üstün gören ve teşhir etmeyi seven narsist kişiler, marka tercihlerinde de pahalı, nadir bulunan ürünlere yönelmektedir. Bunun sebebi olarak narsisizm ile lüks tüketim arasındaki ilişki gösterilebilir.

Aşırı, fazlalık ve ekstra anlamlarına gelen lüks kavramı, kişilerin ihtiyaç duymadığı şeyler olarak tanımlanmaktadır. Fakat lüks kavramı göreceli olup, kişiden kişiye değişmektedir. Diğer bir deyişle, latince 'luxuria' kelimesinden gelen lüks kavramı için yüksek fiyatlı, nadir olan, statü sağlayan ve sıra dışı olarak tanımlanmakta olup, lüks algısı herkes için farklıdır. Tüketiciler genellikle insanlardan farklılaşmak, güçlü bir statüye sahip olmak için lüks tüketime yönelmektedir. Bu bağlamda lüks tüketim yapan tüketiciler haz, prestij, mutluluk ve keyif almaktadır. Lüks tüketim ile yaşanan duyguların kişilerin narsisizmini güçlendirdiği söylenebilir. Çünkü tüketiciler ulaşılması zor, sınırlı sayıda olan, herkesin alamadığı, yüksek fiyatlı lüks markaların ürünlerini kullanarak kendisini özel ve ayrıcalıklı hissetmektedir. Bu durumda kişilerin başkalarına karşı üstün hissetmesine ve statü kazanmasına sebep olmaktadır. Araştırmada ilgili literatür incelendiğinde tüketicilerin lüks markaların ürünlerini kullanarak kendilerini özel ve ayrıcalıklı hissettiği, haz duyduğu görülmektedir (Maden, 2014: 21-31; Tiğlu ve Akyazgan, 2003; Amaldoss ve Jain, 2005). Sezgin'in (2021) araştırmasında tüketici kibrine sahip bireylerin lüks tüketim eğilimleri incelemiştir. Elde edilen bulgulara göre fiziksel görünüm ve başarı kaygısı yaşayan, tüketici kibri yüksek bireylerin, lüks tüketim eğilimlerinin arttı̆̆ görülmektedir. Fakat ilgili literatür incelendiğinde tüketicilerin spesifik kişisel özellikleriyle ilgili yeterli araştırmaya rastlanmamaktadır.

Yukarıdaki bilgiler 1şığında araştırmanın amacını narsist bireylerin lüks tüketime olan eğilimleri arasında anlamlı bir ilişkinin olup olmadığını incelemek oluşturmaktadır. Bu amaç doğrultusunda kolayda örneklem yöntemiyle seçilen Marmara Üniversitesi öğrencilerine anket uygulanmıştır. Elde edilen bulgular doğrultusunda katılımcıların narsisizmi ile lüks 
tüketim eğilimleri arasında anlamlı bir ilişkinin olduğu söylenebilir. Ayrıca çalışmada narsisizmin alt boyutları olan hayranlık ve rekabet faktörünün de katılımcıların lüks tüketim eğilimleri arasındaki ilişki incelenmiştir. $\mathrm{Bu}$ bağlamda elde edilen bilgiler doğrultusunda katılımcıların narsisizmin alt boyutu olan hayranlık ile lüks tüketim eğilimleri arasında anlamlı bir ilişki bulunmaktadır. Bunun yanı sıra katılımcıların narsisizmin diğer alt boyutu olan rekabet ile de lüks tüketim eğilimleri arasında bir ilişkinin olduğu görülmektedir. Bu bilgilerin yanı sıra araştırmada lüks tüketim eğilimlerinin alt boyutları da incelenmiş olup, narsisizmin alt boyutları arasında bir ilişkinin olup olmadığı irdelenmiştir. $\mathrm{Bu}$ çalışmalar sonucunda narsisizmin alt boyutu olan hayranlık boyutu ile katılımcıların lüks tüketim eğilimlerinin alt boyutu olan pahalılıkla da ilişkisinin olduğu görülmektedir. Ayrıca elde edilen diğer verilere göre, narsisizmin alt boyutu olan hayranlık ile katılımcıların lüks tüketim eğilimlerinin alt boyutu olan münhazır bir azınlığa ait olma arasında da ilişki bulunmaktadır. Fakat çalışmada, narsisizmin hayranlık ve rekabet alt boyutu ile lüks tüketim eğilimlerinin alt boyutları olan ürün benzersizliği, sembolik anlam ve keyfi arzuda bir ilişkiye rastlanmamaktadır. Katılımcıların narsisizmin özellikleri ile lüks tüketime olan eğilimleri arasında anlamlı bir ilişkinin olup olmadığının araştırıldığı bu çalışmanın marka yöneticilerin, stratejilerini belirlemesinde yol gösterici olacağına inanılmaktadır. Ayrıca araştırma farklı demografik özelliklere sahip bireylerle ileride yapılabilecek daha kapsamlı çalışmalara yol gösterici olabileceği düşünülmektedir.

$\mathrm{Bu}$ çalışmanın temel amacı, tüketicilerin narsist bireylerin lüks tüketime olan eğilimleri arasında bir ilişkinin olup olmadığının incelenmesidir. Araştırmadan elde edilen veriler doğrultusunda markalar, hedef kitlesinin psikolojik özelliklerini, tutum ve davranışlarını daha iyi anlamlandırabilmektedir. $\mathrm{Bu}$ sayede markalar, hedef kitlelerine ulaşmak, imajlarını kuvvetlendirmek ve tüketicilerinde tutum oluşturmak veya var olan tutumu güçlendirmek amacıyla stratejilerini belirlerken bu çalışmanın sonuçlarından yararlanabilir. Ayrıca yapılan bu araştırma ileride belli markaların seçilmesi veya farklı psikolojik unsurların belirlenmesi gibi, daha kapsamlı araştırmalara da yol gösterici olabileceğine inanılmaktadır. Bu durum da araştırmanın önemini arttırmaktadır.

\section{KAYNAKÇA}

AMALDOSS, W. ve JAIN, S. (2005). "Pricing Of Conspicuous Goods: A Competitive Analysis Of Social Effects”. Journal Of Marketing Research, 42(1): 30-42.

AUDRIN, C., BROSCH, T., CHANAL, J. ve SANDER, D. (2017). "When Symbolism Overtakes Quality: Materialists Consumers Disregard Product Quality When Faced With Luxury Brands". Journal of Economic Psychology, 61: 115-123.

AYTAÇ, M. B. (2019). Tüketicilerin Narsisizm Üzerinden Markaya Yönelik Tutum ve Davranışlarının İncelenmesi, Yayınlanmamış Doktora Tezi, Aksaray.

BBC NEWS, Narsisizm Nedir ve Görülme Sıklı̆̆ı Neden Artıyor? https://www.bbc.com/turkce/haberler-47662973 adresinden 10.11.2020 tarihinde alınmıştır.

BELK, R. (1984). “Three Scales To Measure Constructs Related To Materialism: Reliability, Validity, And Relationships To Measures Of Happiness". Advances İn Consumer Research, 11: 291-297. 
BUFFARDI, L. E. ve CAMPBELL, W. K. (2008). "Narcissism and Social Networking Web Sites". Personality and Social Psychology Bulletin, 34: 1303-1314.

BUSS, D. M. ve CHIODO, L. M. (1991). "Narcissistic Acts in Everyday Life". Journal of Personality, 59(2): 179- 215.

CAMPBELL, K. W. ve FOSTER, J. D. (2007). "The Narcissistik Self: Backgraund, an Extended Agency Model, and Ongoing Controversies”. S. Constantine ve S. J. Spencer içinde, The Self (s. 115-138). Psychology Press Taylor \& Francis Group. New York.

CISEK, S. Z., SEDIKIDES, C., HART, C. M., GODWIN, H. J., BENSON, V. ve LIVERSEDGE, S. P. (2014). Narcissism and Consumer Behaviour: A Review and Preliminary Findings. Frontiers in Psychology, 5(232): 1-9.

DAL, N. E. (2017). “Tüketim Toplumu ve Tüketim Toplumuna Yöneltilen Eleştiriler Üzerine Bir Tartışma”. Mehmet Akif Ersoy Üniversitesi Sosyal Bilimler Enstitüsü Dergisi, 9 (19):1-21.

DANZIGER, P. (2004). Let Them Eat Cake: Marketing Luxury to the Masses As Well As the Classes. USA, Dearborn Trade Publishing.

DEMİRCI, İ. ve EKŞİ, F. (2017). "Büyüklenmeci Narsisizmin İki Farklı Yüzü: Narsistik Hayranlık ve Rekabetin Mutlulukla İlişkisi”. Marmara Üniversitesi Atatürk Eğitim Fakültesi Eğitim Bilimleri Dergisi, 46:37-58.

DOGAN, V., OZKARA, B., Y. ve DOGAN, M. (2020). Luxury Consumption Tendency: Conceptualization, Scale Development and Validation, Current Psychology, 39: 934952.

ELLIS, H. (1898). “Auto-erotism: A Psychological Study”. Alienist and Neurologist, 19(2): 260-299.

ESCALAS, J. E. ve BETTMAN, J. R. (2003). "You are What They Eat: The Influence of Reference Groups on Consumers' Connections to Brand”. Journal of Consumer Psychology, 13:339-348.

FREUD, S. (1914). "On Narcissism. The Standard Edition of the Complete Psychological Works of Sigmund Freud”. Volume XIV (1914-1916): On the History of the PsychoAnalytic Movement, Papers on Metapsychology and Other Works, 67-102.

HARNISH, R. J. ve BRIDGES, K. R. (2015). Compulsive Buying: The Role of Irrational Beliefs, Materialism, and Narcissism. Journal of Rational-Emotive \& CognitiveBehavior Therapy, 33(1):1-16.

HEINE, K. (2012). The Concept of Luxury Brands, 2nd Edition, Www.conceptofluxurybrands.com.

HÜRMERİÇ, P. ve BABAN, E. (2012). “Simmel, Veblen ve Sombart'ın Penceresinden Hedonik Tüketim Ütopyada Negotium ve Otium”. Global Media Journal: Turkish Edition, 2 (4): 87-101. 
KANG, Y-J. ve PARK, S-Y. (2016). "The Perfection of The Narcissistic Self: A Qualitative Study on Luxury Consumption and Customer Equity". Journal of Business Research, $1-7$.

KAPFERER, J. N. (2010, 04 19). The Luxury Strategy: Break The Rules of Marketing to Build Luxury Brands. Brand Management: http://www.brandmanagement.usi.ch/Keynotes/kapferer-Luxury.pdf adresinden 10.11.2020 tarihinde alınmıştır.

KAPFERER, J.-N., KLIPPERT, C. ve LEPROUX, L. (2013). "Does Luxury Have A Minimum Price? An Exploratory Study into Consumers' Psychology of Luxury Prices". Journal of Revenue and Pricing Management, 13 (1): 2-11.

KARAAZIZ, M. ve ATAK, İ. E. (2013). "Narsisizm ve Narsisizmle İlgili Araştırma Üzerine Bir Gözden Geçirme”, Nesne, 1(2): 44-59.

KERNBERG, O. F. (1998). "Pathological Narcissism And Narcissistic Personality Disorder: Theoretical Background And Diagnostic Classification”. In E. F. Ronningstam (Ed.), Disorders Of Narcissism: Diagnostic, Clinical, And Empirical İmplications (Pp. 2951). Northvale, NJ: Jason Aronson.

KUBARYCH, T. S., DEARY, I. J. ve AUSTIN, E. J. (2004). "The Narcissistic Personality Inventory: Factor Structure İn A Non-Clinical Sample”. Personality And İndividual Differences, 36(4): 857-872.

KURTULUŞ, K. (2010). Araştırma Yöntemleri, Türkmen Kitabevi, İstanbul.

LAMBERT, A. ve DESMOND, J. (2013). "Loyal Now, but Not Forever! A Study of Narcissism and Male Consumer-Brand Relationships". Psychology and Marketing, 30(8): 690-706.

MCDONALD, M., WEARING, S. ve PONTING, J. (2007). "Narcissism and NeoLiberalism: Work, Leisure, and Alienation in an Era of Consumption". Loisir et Société / Society and Leisure, 30(2): 489-510.

MEHDIZADEH, S. (2010). "Self-Presentation 2.0: Narcissism and Self-Esteem on Facebook”. Cyberpsychology, Behavıor, And Social Networkıng, 13(4), 357- 364.

NARESH, K. M. ve BIRKS, D. F. (2000). Marketing Research an Applied Approach, Prentice Hall.

ORANSAY, E. (2017). Lüks Ürün Reklamlarındaki Göstergeler: Kişisel Lüks Ürün Reklam Afişleri Üzerine Göstergebilimsel Bir İnceleme. Yayınlanmamış Yüksek Lisans Tezi, İzmir.

ÖZKAYA, S. (2018). Sosyal Medyayı Çok Kullanan Gençlerde Narsistik Kişilik Yapılanması. Yayınlanmamış Yüksek Lisans Tezi, İstanbul.

SALMIVALLI, C. (2001). "Feeling Good About Oneself, Being Bad To Others? Remarks On Self-Esteem, Hostility, And Aggressive Behavior". Aggression And Violent Behavior, 6(4): 375-393.

SEDIKIDES, C., GREGG, A. P., CISEK, S. ve HART, C. M. (2007). "The I That Buys: Narcissists As Consumers". Journal of Consumer Psychology, 17: 254-257. 
SEDIKIDES, C., HART, C. M., CISEK, S. Z. ve ROUTLEDGE, C. (2013). Finding Meaning In The Mirror: The Existential Pursuits Of Narcissists. In J. A. Hicks ve C. Routledge (Eds.), The Experience Of Meaning İn Life (pp. 189-200). New York, NY: Springer.

SEZGIN, K., N. (2021). Tüketici Kibri, Tüketici Sosyalleşmesi ve Popülarite İhtiyacının Lüks Tüketim Üzerindeki Etkilerinin İncelenmesi: Genç Yetişkinler Üzerinde Bir Araştırma. Yayınlanmamış Doktora Tezi, Karabük.

SNYDER, C. R. (1992). "Product Scarcity by Need for Uniqueness İnteraction: A Consumer Catch-22 Carousel?”. Basic and Applied Social Psychology, 13(1): 9-24.

SNYDER, C. R. ve FROMKIN, H. L. (1977). “Abnormality As a Positive Characteristic: The Development and Validation of a Scale Measuring Need for Uniqueness". Journal of Abnormal Psychology, 86(5): 518-527.

TIĞLI, M. ve AKYAZGAN, M. A. (2003). “Özellikli (Lüks) Tüketim Ürünlerinde Enderlik Prensibi ve Bir Uygulama”. Kocaeli Üniversitesi Sosyal Bilimler Enstitüsü Dergisi, 5 (1): 21-37.

TOSUN, N., URALTAŞ, N.T., NAS, A., ÖZKAYA, B., GÜDÜM, S., ERTÜRK, B., DÖNMEZ, M., ÇERÇİ, M, ÜLKER, Y., CESUR, D. K., VAROL, E. ve KİÇİR, İ. (2018). Reklam Yönetimi, Beta Yayım Dağıtım A.Ş., İstanbul.

ÜNLÜ, F. (2018). “Orta Yaş Üstü Bireylerde Sosyal Medya Bağımlılığı ve Sosyal İzolasyon”. PESA Uluslararası Sosyal Araştırmalar Dergisi, 4(1):161-172.

WALLACE, H. M. ve BAUMEISTER, R. F. (2002). "The Performance of Narcissists Rises and Falls With Perceived Opportunity for Glory". Journal of Personality and Social Psychology, 82(5): 819-834.

WONG, N. Y. ve AHUVIA, A. C. (1998). "Personal Taste and Family Face: Luxury Consumption in Confucian and Western Societies". Psychology \& Marketing, 15(5): 423-441.

YAZICI, B. (2019). Yeni Lüks Kavramı Bağlamında Y Kuşağı İle Evrilen Tüketim ve Y Kuşağının Lüks Kavramına Bakışı. Yayınlanmamış Doktora Tezi, İstanbul.

YEOMAN, I. (2011). "The Changing Behaviours of Luxury Consumption". Journal of Revenue and Pricing Management, 10(1): 47-50.

ZHAN, L. ve HE, Y. (2012). "Understanding Luxury Consumption in China: Consumer Perceptions of Best-Known Brands”. Journal of Business Research, 65: 1452-1460. 